\title{
Local governments' efficiency: a systematic literature review-part II
}

\author{
Isabel Narbón-Perpiñáa and Kristof De Witte ${ }^{b, c}$ \\ ${ }^{a}$ Departamento de Economía, Universitat Jaume I, Avda Vicente Sos Baynat s/n, E-12071, Castellón de la Plana, Spain \\ ${ }^{\mathrm{b}}$ Top Institute for Evidence Based Education Research, Maastricht University, Kapoenstraat 2, MD 6200, Maastricht, \\ The Netherlands \\ ${ }^{\mathrm{c}}$ Leuven Economics of Education Research, Katholieke Universiteit Leuven, Naamsestraat 69, 3000 Leuven, Belgium \\ E-mail:narbon@uji.es [Narbón-Perpiñá]; k.dewitte@maastrichtuniversity.nl,Kristof.dewitte@kuleuven.be [Witte]
}

Received 27 October 2016; received in revised form 1 December 2016; accepted 4 December 2016

\begin{abstract}
The efficient management of the available resources in local governments has been a topic of high interest in the field of public sector. We provide an extensive and comprehensive review of the existing literature on local governments' efficiency from a global point of view, covering all articles from 1990 to August 2016. This paper is the second of two. It covers the aspects related to local governments' efficiency measurement along with its determinants, that is, taking into account the effect of environmental variables over efficiency. First, we describe which techniques have been used to incorporate environmental variables in the context of local governments. Second, we provide a classification for the determinants used and summarize their impact on efficiency. Finally, we discuss some operative directions and considerations for further research in the field.
\end{abstract}

Keywords: efficiency; local government; survey; contextual factors

\section{Introduction}

Over the last 30 years, there have been many empirical studies that have focused on the evaluation of efficiency in local governments from multiple points of view and contexts. Following De Borger and Kerstens (1996a), it is possible to identify two strands of empirical research. On the one hand, some studies concentrate on the evaluation of a particular local service, such as refuse collection and street cleaning (Bosch et al., 2000; Worthington and Dollery, 2000, 2001; Benito-López et al., 2011; Benito et al., 2015), water services (García-Sánchez, 2006a), street lighting (Lorenzo and Sánchez, 2007), fire services (García-Sánchez, 2006b), library services (Stevens, 2005) or road maintenance (Kalb, 2012). On the other hand, other studies evaluate local performance from a "global point of view" considering that local governments supply a wide variety of services and facilities. 
From this global point of view, many investigations have attempted to determine whether external factors affect local governments' performance. Municipalities face different environmental conditions in terms of social, demographic, economic, political, financial, geographical and institutional, among others. These environmental variables can have a huge impact on the efficiency scores because they are beyond the control of local managers. For example, municipalities located in tourist areas may have higher costs when providing some public services and facilities during some periods of the year. These municipalities could be unable to achieve the "best practice" due to their relative harsh environment and, as a consequence, leading to biased efficiency results and wrong-headed policy implications. Therefore, if local governments are affected by external factors, performance analysis should control for this heterogeneity. Efficiency estimations, which do not account for the operational environment, have only a limited value (De Witte and Kortelainen, 2013).

We provide a systematic review of the existing literature on determinants of local governments' efficiency from a global point of view, covering all articles from 1990 up to the year 2016. This paper is the second of two. While in the companion paper (Narbón-Perpiñá and De Witte, 2017) we focused on the basic aspects of local governments' efficiency measurement (i.e., input and output indicators, and methods employed), in this paper we take into account the incorporation of environmental variables in the efficiency estimation. More specifically, this paper contributes to the literature in two major aspects. First, it describes which techniques have been used to incorporate environmental variables in the context of local governments. Second, it provides a classification for the operational environment. In local government efficiency measurement, the inclusion of environmental variables is not unanimous since there is a lack of a clear and standard classification (Da Cruz and Marques, 2014). We identify all variables used in previous literature according to the classifications proposed, and comment their correlation with efficiency.

In this paper, the review starts from the 84 articles obtained from the systematic review process carried out in the companion paper (Narbón-Perpiñá and De Witte, 2017). As a new criterion for inclusion, we focus on the studies which included environmental variables in the analysis. Finally, we obtained 63 studies. To the best of our knowledge, these literature reviews are the most complete source of references on local government efficiency analysis. We show a complete overview of the variables selection, the methodologies employed as well as some considerations for further work.

The remainder of the paper is organized as follows. Section 2 provides the methodologies used to incorporate environmental variables in the analysis. Section 3 proposes a classification and comments the impact of the different variables over efficiency. Finally, Section 4 discusses the main conclusions and suggests operative directions for future researchers in the field.

\section{Methodological approaches}

Many studies have dealt with estimating how the contextual variables that face municipalities affect their performance. Table A1 provides a review of the studies using the different approaches to incorporate environmental variables in the efficiency estimation.

On the one hand, the empirical studies on local government efficiency which used traditional non-parametric methodologies (such as DEA or FDH) usually include external or environmental 
variables focusing on three main families of models $^{1}$ : the two-stage approaches (including the semi-parametric bootstrap-based approach), the frontier separation or meta-frontier approach and conditional models.

The first category is based on the two-stage analysis, the most popular method used to include environmental variables in local government efficiency. The efficiency scores are estimated in a first stage and a set of determinants are included in a second stage, using techniques such as Tobit censored regression model, ordinary least squares (OLS) or single and double bootstrap methods (Simar and Wilson, 2007). The multistage approaches assume (implicitly) a separability condition where the operational environment would not influence the input or output levels, but only efficiency. As observed in Table A1, in total 17 papers used Tobit analysis in a second stage, 12 used OLS methods and 11 bootstrapped truncated regressions.

In addition, some studies compared results from different methodologies when they introduced determinants of efficiency in the analysis. For instance, Da Cruz and Marques (2014) compared Tobit, OLS and double bootstrap. Also, Fogarty and Mugera (2013) employed OLS and single bootstrap method, Athanassopoulos and Triantis (1998) used Tobit and fuzzy k-means cluster analysis. De Borger and Kerstens (1996a) used Tobit and OLS, Borge et al. (2008) used OLS and random effects and Bosch-Roca et al. (2012) used Tobit and bootstrap methods. Otherwise, the study of Benito et al. (2010) used Kendall $\tau$ test. Finally, in contrast to previous two-stage research studies, the studies of Balaguer-Coll et al. (2007) and Nikolov and Hrovatin (2013) used non-parametric smoothing techniques instead of econometric methods, which focus on graphical aspects of efficiency results, while Helland and Sørensen (2015) used linear regression and Sampaio de Sousa et al. (2005) used linear regression as well as quantile regression.

The second category refers to the frontier separation or meta-frontier approach. It evaluates separate efficiency performance for different groups according to the environmental characteristics (De Witte and Marques, 2009). In this context, the study of Balaguer-Coll et al. (2013) evaluated the efficiency of Spanish municipalities after splitting them into clusters according to the output mix, environmental conditions and the level of powers.

The third category for including environmental factors is called conditional efficiency, based on a probabilistic formulation of the efficient process formulation. It incorporates the operational environment by conditioning on the external characteristics (Cazals et al., 2002; Daraio and Simar, 2005, 2007). Its main advantage is that it avoids the problem related to the separability condition from two-stage analysis. We found only one study in the literature using this technique (Asatryan and De Witte, 2015). In addition, the study of Cordero et al. (2016) used the time-dependent conditional frontier models recently developed by Mastromarco and Simar (2015).

On the other hand, the empirical studies which used parametric methodologies to estimate local government efficiency (such as Stochastic Frontier Approach, SFA; Aigner et al., 1977; Meeusen and Van den Broeck, 1977) usually include environmental variables focusing on two main families of approaches: the single-stage approach and two-stage analysis.

First, the single-stage approach jointly estimates the efficiency scores including the environmental variables in one stage. As shown in Table A1, in total 19 papers have included environmental variables

\footnotetext{
${ }^{1}$ For a comprehensive review on methods used to include environmental variables in non-parametric efficiency analysis, see the studies of Fried et al. (2008) and De Witte and Kortelainen (2013).
}

(C) 2017 The Authors. International Transactions in Operational Research (C) 2017 International Federation of Operational Research Societies 
using a single-stage approach. Second, as commonly used with non-parametric two-stage models, the efficiency scores obtained in a first step via parametric methodologies are regressed in a second step with a set of determinants, using techniques such as OLS or Tobit censored regression. In fact, three studies used Tobit analysis in a second step and two used OLS.

\section{Environmental variables}

The efficiency analysis literature does not provide a clear and standard classification of the external or environmental variables to include in the analysis. In contrast to the study of Da Cruz and Marques (2014), who proposed a classification for the different type of determinants, we classify the observed variables in six main categories: social and demographic, political, financial, economic, geographical or natural and, institutional or managerial. Table A2 shows the classification of the environmental variables included. Table A3 summarizes the studies containing the variables included in the proposed classification.

Additionally, we note that in many cases the effects of the determinants present ambiguous effects over efficiency, that is, results from different studies are mixed. These unclear effects can be explained by the different characteristics of each country and the availability of data. We discuss every single variable from Table A3, describing the results shown in previous studies and the expected impact of each variable over efficiency.

\subsection{Social and demographic determinants}

This group of environmental variables is composed of citizens' related characteristics. It is explained by eight indicators: population density, population growth, population size, age distribution of the population, education level, share of immigrants, share of homeowners and others.

- Population density (37 papers)

The population density is measured as the number of inhabitants of each municipality divided by its extension, mostly expressed in squared kilometres. Based on previous empirical studies, the influence of this variable is not, a priori, clear and we have alternative hypothesis on the effect that population density has on efficiency. On the one hand, it affects the cost of providing public services, that is, economies of scale could exist when population concentration rises (cost advantages). Hence, it would enhance efficiency. ${ }^{2}$ Moreover, some studies included "urbanization rate" as a variable to capture scale effects. ${ }^{3}$ They suggested that an increase in the urbanization rate leads to higher levels of efficiency. Similarly, Balaguer-Coll et al. (2013) used the total surface area divided by population as a proxy for urban sprawl as well as urbanized municipalities.

On the other hand, if the population concentration is larger, the cost of providing public services can become higher (problems of agglomeration and higher complexity). Thus, the provision of

${ }^{2}$ De Borger and Kerstens (1996a), Sampaio de Sousa et al. (2005), Sung (2007), Afonso and Fernandes (2008), Geys et al. (2010), Kalb (2010), Bönisch et al. (2011), Boetti et al. (2012), Bischoff et al. (2013), Fogarty and Mugera (2013), Carosi et al. (2014), Agasisti et al. (2015), Radulovic and Dragutinović (2015), Yusfany (2015), Lo Storto (2016).

${ }^{3}$ Loikkanen and Susiluoto (2005), Sampaio de Sousa et al. (2005), Bruns and Himmler (2011), Loikkanen et al. (2011). 
the service would be less efficient. ${ }^{4}$ However, there are also research studies which found that population density is not statically significant. ${ }^{5}$ Additionally, the studies of Kalseth and Rattsø (1995) and Revelli and Tovmo (2007) introduced the variable "settlement pattern", calculated as the travelling distance to the administration centre of the local authority, to measure sparseness of population. The first study found that a decentralized settlement pattern seems not to be an important factor, while the second suggested that more sparsely populated areas manage to achieve higher levels of efficiency.

- Population growth (7 papers)

Total population growth is the variation of inhabitants (in percentage) that municipalities face over the years. If the population growth is high, municipalities must increase local services and infrastructures proportionally because population's demand has also increased. If they do it properly, efficiency levels would improve. For instance, Afonso and Fernandes (2008) showed a positive and significant relation with efficiency - but only in the North Region of Portugal. In contrast, if they do not keep pace with the proportional increase of services and infrastructures, they might face an imbalance and we will expect a negative relation with efficiency. ${ }^{6}$ Otherwise, some studies concluded that a demographic change does not cause significant efficiency effects. ${ }^{7}$

- Population size (24 papers)

Population size is mostly measured as the total population for each local government as well as dummy variables representing different population groups. The effect of this variable over efficiency is, a priori, ambiguous. A common intuition is that economies of scale and agglomeration externalities typically make larger municipalities more efficient. ${ }^{8}$ However, the negative effects of having a larger population (scale inefficiencies) were also confirmed by some studies. ${ }^{9}$ Otherwise, results in the study of Doumpos and Cohen (2014) did not follow a linear pattern (the coefficient was negative for small municipalities and positive for medium and large municipalities). Finally, Andrews and Entwistle (2015) did not find population size related to efficiency.

- Age distribution of the population (10 papers)

The different age distribution of the population can have an impact on the different needs that local governments have to satisfy. Mainly, two variables are included: share of young people (18 years old or below) and share of retired people (over 65 years old). First, higher percentages of young population demand higher levels of social and recreational services to the public administrations (for instance, kindergartens, gyms or playing fields among others), so there is

\footnotetext{
${ }^{4}$ Athanassopoulos and Triantis (1998), Geys (2006), Geys and Moesen (2009), Kalb et al. (2012), Geys et al. (2013), Da Cruz and Marques (2014), Doumpos and Cohen (2014), Lampe et al., (2015).
}

${ }^{5}$ Giménez and Prior (2007), Revelli and Tovmo (2007), Revelli (2010), Ashworth et al. (2014), Pevcin (2014a, 2014b), Andrews and Entwistle (2015), Arcelus et al. (2015), Cordero et al. (2016).

${ }^{6}$ Kalseth and Rattsø (1995), Balaguer-Coll et al. (2013).

${ }^{7}$ Bönisch et al. (2011), Bischoff et al. (2013), Monkam (2014).

${ }^{8}$ De Borger et al. (1994), Kalseth and Rattsø (1995), Grossman et al. (1999), Balaguer-Coll et al. (2007), Giménez and Prior (2007), Benito et al. (2010), Revelli (2010), Bruns and Himmler (2011), Boetti et al. (2012), Nakazawa (2013), Carosi et al. (2014), Nakazawa (2014), Asatryan and De Witte (2015), Pérez-López et al. (2015).

${ }^{9}$ Loikkanen and Susiluoto (2005), Sung (2007), Geys and Moesen (2009), Loikkanen et al. (2011), Štastná and Gregor (2011), Ashworth et al. (2014), Sørensen (2014), Štastná and Gregor (2015).

(C) 2017 The Authors. International Transactions in Operational Research (C) 2017 International Federation of Operational Research Societies 
an incentive for municipal administrators to improve efficiency (Agasisti et al., 2015). However, this higher spending on public services could also affect efficiency negatively (Nakazawa, 2013, 2014). Other studies found the share of young population not statistically significant. ${ }^{10}$

Second, retired people could have higher control over council performance because they take part in organizations of local nature (Bosch-Roca et al., 2012). However, the share of retired people over population could have a negative effect since this population group is more likely to use health care and nursing services. ${ }^{11}$ Otherwise, some studies concluded that the share of retired people has no statistical significance. ${ }^{12}$ Finally, the study of Radulovic and Dragutinovic (2015) included an "ageing index", that is, a ratio between the number of people over 65 and the number of people under 18, while Andrews and Entwistle (2015) included the age diversity. Only Radulovic and Dragutinović (2015) found significant results, showing a negative relation between the age index ratio and efficiency.

- Education level (17 papers)

Education level includes primary, secondary and tertiary education. On the one hand, highly educated citizens might be more effective in demanding more efficient government since education has an effect on political participation and control. Moreover, municipalities with larger proportion of educated people may imply a more qualified labour force. Therefore, it would have a positive correlation with efficiency. ${ }^{13}$ Moreover, the study of Da Cruz and Marques (2014) found that higher illiteracy is related to inefficiency.

In contrast, the studies of De Borger and Kerstens (1996a) and Štastná and Gregor (2011, 2015) showed a negative correlation with efficiency. Finally, some of the studies found that the education level is not related to local government efficiency. ${ }^{14}$

- Immigration share and ethnic diversity 6 papers)

The share of immigrants is the percentage of foreign inhabitants related to the total population of a municipality. This variable is assumed to decrease cost efficiency because foreign population does not have right to vote (Bosch-Roca et al., 2012) or are less interested in politics (Bruns and Himmler, 2011). In addition, the study of Lampe et al. (2015) introduces the migration rate (measured as the immigration rate less the migration rate) to measure the municipality's popularity. They found that migration rate is positively correlated to efficiency as it increases the population and the services of a municipality in a short term, while expenditures will not increase in the same proportion (in the respective year).

Otherwise, Nikolov and Hrovatin (2013) studied "ethnic fragmentation", arguing that more ethnically fragmented municipalities exhibit less efficiency. Similarly, Revelli (2010) and Andrews and Entwistle (2015) included indicators of ethnic composition (percentage of the population that is white) and ethnic diversity (16 groups), concluding that higher ethnic diversity has a negative

${ }^{10}$ Giménez and Prior (2007), Bruns and Himmler (2011), Asatryan and De Witte (2015).

${ }^{11}$ Bönisch et al. (2011), Bischoff et al. (2013), Nakazawa (2013, 2014), Da Cruz and Marques (2014).

${ }^{12}$ Giménez and Prior (2007), Bruns and Himmler (2011), Agasisti et al. (2015).

${ }^{13}$ De Borger et al. (1994), De Borger and Kerstens (1996b), Loikkanen and Susiluoto (2005), Afonso and Fernandes (2008), Revelli (2010), Loikkanen et al. (2011), Da Cruz and Marques (2014), Monkam (2014), Radulovic and Dragutinović (2015).

${ }^{14}$ Ibrahim and Karim (2004), Geys and Moesen (2009), Bruns and Himmler (2011), Bosch-Roca et al. (2012). 
correlation with efficiency. Also, Hayes and Chang (1990) used the percentage of the population that is minority, however they did not find significant correlation with efficiency.

- Share of homeowners (3 papers)

Share of homeowners represents the amount of owner-occupiers over local government population. Homeownership entails a significant financial investment, so homeowners demand more efficient government behaviour and monitor local politicians (Hayes and Chang, 1990; Geys, 2006). Otherwise, the study of Geys and Moesen (2009) did not find significant relation to local government efficiency.

- Other determinants related to social and demographic characteristics

Finally, we include other determinants related to social and demographic characteristics which are not classified in the previous subcategories. Agasisti et al. (2015) included the number of families, suggesting that the more families within the municipality, the more services different from the essential ones will be requested, so it has a positive correlation with efficiency. Moreover, Bruns and Himmler (2011) included the average household size as well as the commuter share, however they did not find significant results. Nakazawa (2013) included the ratio of daytime to night-time population, which had negative effects over efficiency, and Revelli (2010) used the share of disabled workers but they did not find significant results.

In addition, Andrews and Entwistle (2015) included the social class diversity (however, they did not find significant results). Lo Storto (2016) and Da Cruz and Marques (2014) included the crime rate, suggesting that when the level of urban crimes grows, the municipality efficiency increases. Finally, Revelli (2010) and Bruns and Himmler (2011) included the share of religious population. While the first study suggested that religious people are associated with better government performance, the second study argued that a higher share of religious population is associated with lower levels of efficiency since they are possibly less interested in local politics.

\subsection{Economic determinants}

This group of environmental variables is composed by variables related to the economic situation of each local government. It is explained by seven indicators: unemployment, citizen's disposable income, economic status, tourist index, commercial activity, industrial activity and others.

- Unemployment (15 papers)

The variable unemployment is measured as the percentage of unemployment related to the working population of each municipality. A difficult socio-economic municipal situation (i.e., a high unemployment rate) implies higher spending on social and housing benefits, so it tends to decrease efficiency ("cost effect"). ${ }^{15}$ However, unemployment could imply lower demand for high-cost or high-quality public services ("preference effect"), so it will be expected to have higher levels of efficiency (Geys et al. 2010; Kalb 2010; Lampe et al. 2015). Other studies indicated that unemployment is not related to municipal efficiency. ${ }^{16}$

${ }^{15}$ Loikkanen and Susiluoto (2005), Revelli (2010), Loikkanen et al. (2011), Kalb et al. (2012), Pevcin (2014a, 2014b), Pérez-López et al. (2015), Radulovic and Dragutinović (2015).

${ }^{16}$ Balaguer-Coll and Prior (2009), Geys and Moesen (2009), Bönisch et al. (2011), Geys et al. (2013), Cordero et al. (2016). 
- Citizen's income level or purchasing power (26 papers)

The variable income per capita represents the citizen's economic level estimated for each municipality. On the one hand, municipalities which have richer local residents have an increased population pressure to provide efficient local services. These higher income citizens might pay greater taxes and, as a consequence, they will have more requirements on local services and facilities. Therefore, higher citizens' incomes would increase efficiency. ${ }^{17}$ Similarly, Agasisti et al. (2015) used a taxable income per capita (a progressive tax on all the income of a person called IRPEF) as a proxy of the average income per capita. The higher it is, the more citizens' supervision on municipal administrators, so it is positively related to efficiency. Balaguer-Coll et al. (2013) and Da Cruz and Marques (2014) proxied the economic status with the capita GDP, however, only Balaguer-Coll et al. (2013) found a positive relation with efficiency.

On the other hand, if local governments have higher financial resources (because they collect higher incomes), interest of the politicians in reaching efficiency in the provision of local services and facilities is reduced. In addition, citizens from high-income municipalities may be less motivated to monitor expenditures. So, it would be negatively related to efficiency. ${ }^{18}$ In a similar way, Cuadrado-Ballesteros et al. (2013) measured income level using the variable GDP per capita, and their results present a negative correlation with efficiency. Other studies concluded that citizen's income did not have a significant relation with efficiency. ${ }^{19}$

Additionally, Geys and Moesen (2009) and Ashworth et al. (2014) included "income inequality" to assess the effect of income heterogeneity in the population. Only Ashworth et al. (2014) found negative significant results.

- Municipal economic situation (6 papers)

The determinants within this subcategory refer to variables related to the economic situation of each municipality. Sampaio de Sousa et al. (2005) used the average earnings as a poverty proxy as well as a dummy variable for those municipalities which took part in the Alvorada Program (a federal program for low income municipalities). They found that poor cities, especially those participating in the Alvorada Program, tend to be more efficient. Similarly, Lo Storto (2016) used the value added per inhabitant as a proxy of the economical context, suggesting that higher efficiency is associated to less rich contexts. Otherwise, Revelli (2010) and Andrews and Entwistle (2015) included a deprivation index to capture the levels of disadvantage in income, employment, health, education, housing, crime and environment. They showed a negative relationship with efficiency, indicating that providing public services in disadvantaged areas is an especially challenging task. Fogarty and Mugera (2013) measured the relative socio-economic disadvantage. They hypothesized that councils with higher socio-economic disadvantage would have lower efficiency scores, however, they do not find significant results. Finally, Balaguer-Coll

\footnotetext{
${ }^{17}$ Ibrahim and Karim (2004), Afonso and Fernandes (2008), Afonso et al. (2010), Boetti et al. (2012), Asatryan and De Witte (2015).

${ }^{18}$ De Borger et al. (1994), De Borger and Kerstens (1996a, 1996b), Loikkanen and Susiluoto (2005), Sampaio de Sousa et al. (2005), Giménez and Prior (2007), Bruns and Himmler (2011), Bosch-Roca et al. (2012), Nikolov and Hrovatin (2013), Ashworth et al. (2014), Da Cruz and Marques (2014), Monkam (2014).
}

${ }^{19}$ Geys (2006), Balaguer-Coll and Prior (2009), Geys and Moesen (2009), Benito et al. (2010), Yusfany (2015), Cordero et al. (2016). 
et al. (2013) included the number of bank branches to proxy for the economic level of the municipality.

- Tourist activity (13 papers)

Tourism measures the importance of the tourist activity of each municipality. On the one hand, seasonal population has an impact on the provision of services because local governments must face higher investments during some periods of the year. Moreover, tourists have a greater demand for higher quality public services that increase the costs. Hence, we will expect that an increase in the tourist index has a negative correlation with efficiency. ${ }^{20}$ On the other hand, Giménez and Prior (2007) and Pérez-López et al. (2015) found a positive relation between this variable and efficiency, concluding that the more tourism activity, the lower the cost excess. Finally, some studies found that tourism is not statistically significant. ${ }^{21}$

- Commercial activity (4 papers)

This variable measures the importance of the commercial activity of each municipality. High commercial activity means more pressure over local managers to improve efficiency because traders exercise more control. Therefore, we expect a positive relation to efficiency. ${ }^{22}$ However, Sung (2007) showed that an increase in the number of establishments and service-related establishments may reduce efficiency since more time and effort by local servants is required.

- Industrial activity (2 papers)

This variable measures the importance of industrial activity of each municipality. We can hypothesize that more efficient municipalities will attract business, so it will enhance efficiency (Geys and Moesen, 2009). On the contrary, the study of Giménez and Prior (2007) concluded that the industry activity has no relation with efficiency.

- Other determinants related to economic characteristics

Finally, we include other determinants related to economic characteristics which are not classified in the previous subcategories. Sampaio de Sousa et al. (2005) measured the municipalities that receive substantial royalty revenues (on oil and water), suggesting that extra revenues, rather than encouraging the optimal use of resources, contribute to a decrease in efficiency. Moreover, the study of Revelli (2010) included the percentage of self-employed population, which had a negative correlation with efficiency. Also, Revelli (2010) included the property tax base to capture income effects on the demand for public services, which were estimated to have a positive effect on performance. Otherwise, Balaguer-Coll et al. (2013) and Geys and Moesen (2009) indicated whether it is a rural municipality (whose needs might differ from others with different sectoral specializations), while Balaguer-Coll et al. (2013) also included municipalities where construction was higher. Finally, Da Cruz and Marques (2014) included the automotive fuel consumed and new vehicles sold as a measure for the economic consumption levels, showing a positive correlation with efficiency.

\footnotetext{
${ }^{20}$ Geys and Moesen (2009), Kalb (2010), Bosch-Roca et al. (2012), Kalb et al. (2012), Cuadrado-Ballesteros et al. (2013), Carosi et al. (2014), Da Cruz and Marques (2014).

${ }^{21}$ Sampaio de Sousa et al. (2005), Balaguer-Coll and Prior (2009), Benito et al. (2010), Lampe et al. (2015).

${ }^{22}$ Giménez and Prior (2007), Balaguer-Coll and Prior (2009), Bosch-Roca et al. (2012).
} 


\subsection{Political determinants}

We have focused on the impact of political and legal determinants on efficiency including five indicators: ideological position, political concentration/fragmentation or strength, voter turnout, re-election and others.

\section{- Ideological position (26 papers)}

The ideological position represents local governments' political sign. The basic hypothesis is that left-wing parties prefer a larger public sector which, in general, is associated with low efficiency levels. ${ }^{23}$ Similarly, the study of Sørensen (2014) concluded that electoral polarization (distance between the socialist and non-socialist party blocs) causes lower government performance. Moreover, Geys (2006) and Štastná and Gregor (2015) introduced measures for the ideological fragmentation of the governing coalition. Only Štastná and Gregor (2015) found significant evidence, concluding that the strength of a left-wing mayor seems to further increase cost inefficiency.

However, the available evidence is not entirely unidirectional, since the studies of De Borger et al. (1994) and De Borger and Kerstens (1996a, 1996b) concluded that the presence of the socialist party is associated with higher efficiency. Similarly, Andrews and Entwistle (2015) suggested that Labour vote shares are positively related to productive efficiency, suggesting that whether is a greater support to public services, local authorities may find less difficult to make the best use of their resources. Also the studies of Geys et al. (2010) and Agasisti et al. (2015) concluded that a low share of left-wing parties is associated with lower efficiency. Other studies, however, concluded that the ideological position did not have a significant influence on efficiency. ${ }^{24}$ Additionally, Boetti et al. (2012) and Bruns and Himmler (2011) measured governing coalitions with a civic list, which are not identified with any ideological position and are associated with higher efficiency, while Štastná and Gregor (2011) introduced a dummy for parliamentary parties (less votes for parliamentary parties implies more votes for local parties with no ideology).

- Political concentration/fragmentation and political strength (25 papers)

Most of the studies that measure political concentration in local government calculate the Herfindahl index. It takes values between 0 and 1, indicating a higher degree of political concentration (or a lower degree of political fragmentation) and, as a result, a higher degree of political strength (or lower degree of competition). On the one hand, when the degree of political concentration is higher, there exist a lower political opposition and it is easier to implement policies and impose budget constraints, so it is expected to increase efficiency. ${ }^{25} \mathrm{On}$ the other hand, a low political competition makes more difficult for other parties to control

\footnotetext{
${ }^{23}$ Revelli and Tovmo (2007), Borge et al. (2008), Kalb (2010), Revelli (2010), Loikkanen et al. (2011), Štastná and Gregor (2011), Kalb et al. (2012), Ashworth et al. (2014), Da Cruz and Marques (2014), Doumpos and Cohen (2014), Helland and Sørensen (2015).

${ }^{24}$ Geys and Moesen (2009), Benito et al. (2010), Boetti et al. (2012), Sørensen (2014), Asatryan and De Witte (2015), Pérez-López et al. (2015), Cordero et al. (2016).

${ }^{25}$ Revelli and Tovmo (2007), Borge et al. (2008), Bruns and Himmler (2011), Štastná and Gregor (2011), Doumpos and Cohen (2014), Pacheco et al. (2014), Yusfany (2015).
} 
expenditures and therefore efficiency can be reduced. ${ }^{26}$ Finally, some studies found no statistical significance. $^{27}$

Moreover, other variables related to political concentration and strength different from the Herfindahl index have been used. For instance, De Borger et al. (1994) introduced the number of coalition parties, while Ashworth et al. (2014) introduced variables reflecting different aspects of the local government competition as well as the variables "single-party government" and "number of coalition parties" to capture the effect of government fragmentation. The first study argues that political coalitions may affect technical efficiency because arbitrage in the bargaining process may require more payments, however, they did not find significant results. The second study found that government fragmentation and coalitions have a significant negative correlation with efficiency. Similarly, Eeckaut et al. (1993) measured political majorities from different parties as well as coalitions, concluding that local governments with multiple party coalitions are more efficient than municipalities governed by a single party. Otherwise, the studies of Athanassopoulos and Triantis (1998) and Nikolov and Hrovatin (2013) measured the coalition between central government and local government, while the study of Pacheco et al. (2014) used the percentage of council representatives who belongs to the governmental coalition. The first two studies presented contrary results, leading Athanassopoulos and Triantis (1998) to lower levels of efficiency and the Nikolov and Hrovatin (2013) to higher levels, while Pacheco et al. (2014) did not show significant results.

In addition, Sørensen (2014) included "electoral dominance" as the share of election periods wherein a party bloc received more than $60 \%$ of the votes. They concluded that party competition leads to higher levels of efficiency. Also, Cuadrado-Ballesteros et al. (2013) introduced variables reflecting different aspects of the local government competition (difference between the percentages of votes obtained by the parties coming in first and second place) as well as political strength (percentage of seats obtained by the governing party). Similarly, Pérez-López et al. (2015) introduced "political strength", concluding that parties governing with an absolute majority present lower levels of efficiency. Finally, the study of Balaguer-Coll et al. (2007) found a negative correlation between efficiency and the relative importance of votes held by the governing party, while Monkam (2014) revealed a positive coefficient of the percentage of council seats held by the majority.

- Voter turnout and democratic participation (9 papers)

The variable voter turnout represents the political participation of the citizens in local elections, that is, the voter turnout related to the citizens entitled to vote. This variable affects the degree of control that inhabitants have over politicians with their votes in local elections, so we expect an improvement in the efficiency of the municipalities. ${ }^{28}$ However, results in Da Cruz and Marques (2014) and Asatryan and De Witte (2015) suggested a negative correlation with efficiency, supporting that less efficient governments motivate more citizen participation. Finally, some studies concluded that voter turnout do not explain efficiency differences (Revelli and Tovmo, 2007; Loikkanen et al., 2011).

\footnotetext{
${ }^{26}$ Balaguer-Coll et al. (2007), Geys et al. (2010), Kalb (2010), Loikkanen et al. (2011), Kalb et al. (2012), Geys et al. (2013), Helland and Sørensen (2015).

${ }^{27}$ Geys (2006), Revelli (2010), Sørensen (2014).

${ }^{28}$ Borge et al. (2008), Geys et al. (2010), Štastná and Gregor (2011, 2015).
} 
Moreover, additional variables related to democratic participation are considered. Bosch-Roca et al. (2012) and Geys et al. (2010) employed the variable "potential electors" (citizens entitled to vote related to total population), which is expected to increase efficiency. Moreover, Geys et al. (2010) included the variable "free voter unions" as an indicator of voter involvement, arguing that their existence improves efficiency since citizens actively participate in politics. Finally, Asatryan and De Witte (2015) considered dummies for citizens initiatives, associated with higher government efficiency.

- Re-election and number of years for elections (5 papers)

Re-election or second mandate represents a municipal mayor that has been re-elected at the municipal elections. Similarly, "new government" represents when a different government has been elected. On the one hand, re-election can have a positive effect on efficiency because at the second mandate the municipality's government has become more competent on local issues. On the other hand, in a second mandate local administrator could tend to spend in a less prudent manner, since they have been elected again (Carosi et al., 2014). Other studies found re-election not statistically significant (Da Cruz and Marques, 2014; Doumpos and Cohen, 2014).

In addition, variables related to the number of years for elections are considered. Boetti et al. (2012) used the variable "electoral mandate" which represents the number of years since the mayor and the governing coalition were elected, in order to test the presence of opportunistic behaviour by local politicians attributable to the electoral budget cycle, however they did not find significant results. Similarly, Agasisti et al. (2015) measured the years that remain until the end of municipal term, which is positively related to efficiency.

- Other determinants related to political characteristics

Finally, we include other determinants related to political characteristics which are not classified in the previous subcategories. Bruns and Himmler (2011) introduced the number of municipality council seats per 1000 inhabitants, which was found positively related to efficiency. They also included local newspaper reach, which is associated with higher efficiency, arguing that newspapers are a major provider of the political information that voters use to monitor their elected officials. Moreover, Grossman et al. (1999) included both Mayor-council form of government and Mayor elected in a general election, however, they showed no significant results. Finally, Helland and Sørensen (2015) included the variables "partisan bias" (voters who vote for party labels and do not care about performance) and "electoral volatility". Their main hypothesis is that non-partisans want better performance and care little about ideology, while partisans vote for labels and care little about high performance. They found that efficiency decreases when the relative partisan bias of the incumbent increases, particularly in municipalities with large electoral volatility.

\subsection{Financial determinants}

We have included a group of environmental variables related to fiscal and financing mechanisms of the local governments. It is explained by five indicators: self-generated, grants and transfers, debt or financial liabilities, surplus and others.

- Self-generated revenues (25 papers)

Self-generated revenues are the total amount of taxes, fees and charges collected by each local government. On the one hand, when local councils are more able to generate revenues 
(by collecting higher taxes), politicians are less motivated to manage them properly. Moreover, these local governments will have good services even if they are not efficient. As a consequence, this variable would have a negative correlation with efficiency. ${ }^{29}$ Similarly, Agasisti et al. (2015) measured the incidence of the proceeds of public services suggesting that higher revenues different from taxes influence negatively the efficiency of the local administrations. Moreover, Carosi et al. (2014) used the ratio of total revenues over total resident population arguing that the more resources are available for a municipality, the greater is the possibility to waste resources. On the other hand, higher taxes will increase citizen control on public management, so it will be expected to have better levels of efficiency. ${ }^{30}$ Other studies showed that tax revenues are not correlated with efficiency. $^{31}$

Additionally, some studies used the share of own taxes in local governments' total revenues as a proxy of fiscal autonomy. ${ }^{32}$ They found that fiscal autonomy has a positive correlation with efficiency supporting that the higher the revenues from fees and taxes (i.e., from citizens contribution), the higher the responsibility of the local government.

- Transfers or grants (26 papers)

Transfers or grants represent the municipal revenues which come from transfers or grants received from higher government levels. Also, the financial independence from central governments (i.e., less transfers and grants received) is employed. Local governments, which have greater security in obtaining resources via grants, are less efficient because politicians will take less care in managing them adequately. Moreover, there will be less citizen control over public management because the cost of inefficient performance is shared by regional and national taxpayers (i.e., they do not pay these revenues directly). Hence, we will expect a negative correlation with efficiency. ${ }^{33}$

On the contrary, some studies showed a positive association with efficiency, explaining that transfers and grants are linked to a more accurate control of local expenditures by higher levels of government. ${ }^{34}$ Moreover, Bischoff et al. (2013) found that the relationship between vertical grants and efficiency is mixed, since they found a positive relationship between grants and efficiency but a negative relationship between fiscal capacity and efficiency. Finally, some studies indicated that transfer grants have no statistical significance (Worthington, 2000; Boetti et al., 2012).

\footnotetext{
${ }^{29}$ Athanassopoulos and Triantis (1998), Grossman et al. (1999), Moore et al. (2005), Balaguer-Coll et al. (2007), Revelli and Tovmo (2007), Sung (2007), Borge et al. (2008), Balaguer-Coll and Prior (2009), Štastná and Gregor (2011), Boetti et al. (2012), Bosch-Roca et al. (2012), Nikolov and Hrovatin (2013), Ashworth et al. (2014), Pérez-López et al. (2015), Štastná and Gregor (2015).

${ }^{30}$ De Borger and Kerstens (1996a, 1996b), Benito et al. (2010).

${ }^{31}$ Fogarty and Mugera (2013), Doumpos and Cohen (2014), Arcelus et al. (2015), Yusfany (2015).

${ }^{32}$ Boetti et al. (2012), Carosi et al. (2014), Da Cruz and Marques (2014), Monkam (2014).

${ }^{33}$ De Borger and Kerstens (1996a, 1996b), Athanassopoulos and Triantis (1998), Grossman et al. (1999), Loikkanen and Susiluoto (2005), Balaguer-Coll et al. (2007), Borge et al. (2008), Balaguer-Coll and Prior (2009), Geys et al. (2010), Kalb (2010), Štastná and Gregor (2011), Bosch-Roca et al. (2012), Da Cruz and Marques (2014), Doumpos and Cohen (2014), Pacheco et al. (2014), Agasisti et al. (2015), Pérez-López et al. (2015), Štastná and Gregor (2015), Yusfany (2015).
}

${ }^{34}$ Worthington (2000), Geys (2006), Geys and Moesen (2009), Bönisch et al. (2011), Ashworth et al. (2014). 
- Debt or financial liabilities (14 papers)

Outstanding debt is the value of the financial unresolved liabilities at the end of the financial year. When local governments have an excess on expenditures over revenues, they will need to take out loans. The first hypothesis is that local governments which make loans are those with low fiscal revenue capacity. These local governments might be more concerned about cost saving due to their financial problems. Moreover, debt can be the result of past investments on equipment that enhance current efficiency. Therefore, considering these reasons, debt would be positively related to efficiency. ${ }^{35}$

On the contrary, if the amount of local government debt is higher, there will be more resources employed to attend debt interests and amortization payments and, as a consequence, less resources will be employed in the provision of local services. Hence, the variable would be negatively related to efficiency. ${ }^{36}$ Other studies showed that debt is not statically significant. ${ }^{37}$ In addition, BalaguerColl et al. (2007) considered also the financial deficit. If deficit rises, local governments will have a financial weaker situation to face their present and future responsibilities. Hence, deficit is negatively correlated with efficiency.

- Surplus (6 papers)

Fiscal surplus is the excess from the year's budget. The main hypothesis is that municipalities that have higher surpluses have better financial performance and also witness higher government efficiency ratings. ${ }^{38}$ Similarly, Pérez-López et al. (2015) used the "Non-financial Current Budgetary result Index", which presented a positive and significant relationship with municipal cost efficiency. On the contrary, Yusfany (2015) showed a negative and significant correlation between surplus and efficiency, stating that local bureaucrats in every year's budget tends to maximize the size of the budget in order to create opportunities to take advantage of local budgets freely according to his personal wishes.

- Infrastructure investments (7 papers)

Infrastructure investments and capital expenditures aim at measuring the effect of a higher level of investments on the use of the financial means. High capital investment in a given year encourages cost savings on current expenditures. Therefore, higher investment expenditure would increase municipal efficiency. ${ }^{39}$ Similarly, Arcelus et al. (2015) considered that municipalities with higher accumulated past investments in infrastructures are expected to have more modern endowments and, therefore, more efficient performance. On the contrary, the study of Štastná and Gregor (2011) found a negative correlation with efficiency. Moreover, Agasisti et al. (2015) included the variables "propensity to invest per capita" and "incidence of capital expenditures on total expenditures". They found that investment was negatively correlated with efficiency, while capital

\footnotetext{
${ }^{35}$ Worthington, 2000; Benito et al., 2010.

${ }^{36}$ Geys (2006), Geys and Moesen (2009), Bönisch et al. (2011), Štastná and Gregor (2011), Bischoff et al. (2013), Ashworth et al. (2014), Da Cruz and Marques (2014), Cordero et al. (2016).

${ }^{37}$ Balaguer-Coll et al. (2007), Revelli and Tovmo (2007), Balaguer-Coll and Prior (2009), Benito et al. (2010), Pérez-López
et al. (2015).
}

${ }^{38}$ Geys (2006), Geys and Moesen (2009), Ashworth et al. (2014), Agasisti et al. (2015).

${ }^{39}$ Athanassopoulos and Triantis (1998), Pacheco et al. (2014), Štastná and Gregor (2015). 
was positively correlated since municipalities exposed to long-term expenditures would be more careful managing the current expenditures.

Additionally, Doumpos and Cohen (2014) employed the annual depreciation to cumulative depreciation ratio as an indicator of the assets' age. The higher the value of the ratio, the newer the infrastructure used for rendering services to citizens. They found a statistically significant positive correlation, arguing that new assets have less maintenance and less operating expenses compared to their older counterparts.

- Other determinants related to financial characteristics

Finally, we include other determinants related to financial characteristics which are not classified in the previous subcategories. Kalb (2010) included dummy variables for abundant and financially weak municipalities to control for financial power of a municipality. Both variables are positive and statistically significant, supporting that abundant or financially weak municipalities have (in relation to financially very weak municipalities) more money to spend and it enables to afford more or qualitatively higher public goods and services. Pérez-López et al. (2015) introduced the variable "cash index". They concluded that the greater the availability of resources, the more efficiency requirements will be relaxed since municipalities can cover their cost increases. Benito et al. (2010) used working capital as an indicator of the local government short-term financial situation.

Moreover, Andrews and Entwistle (2015) included the "Formula Spending Share (FSS) per resident" as a measure of quantity of service needs (this index is used by central government to distribute grant funding to local authorities), as well as the discretionary resources available to each local authority, derived by dividing its total expenditure by its FSS in the same year. They concluded that councils spending beyond the needs of a local population could be seen as an indicator of poor financial performance. Revelli (2010) used the excess spending defined as local public spending per capita minus standard spending per capita set by central government. They suggested that local public expenditures in excess of centrally set spending standards have a detrimental effect on performance. Otherwise, Da Cruz and Marques (2014) and Agasisti et al. (2015) measured the average payment period to suppliers and the speed of payment of current expenditures. Only Da Cruz and Marques (2014) found significant negative results. Finally, Worthington (2000) showed that the higher the level of current assets and current assets relative to current liabilities, the higher the level of technical efficiency.

In addition, some studies included variables related to financial constraints. Boetti et al. (2012) included the effect of the Domestic Stability Pact (DSP), a mechanism of fiscal discipline which leads to cuts in excess spending. They found that municipalities subject to the DSP are more efficient due to the higher control from central government on spending through fiscal rules. Also, Borge et al. (2008) included a dummy variable for centralized budgetary procedure, which was found to be correlated with low efficiency. Finally, Doumpos and Cohen (2014) introduced the administrative expenses to own revenues ratio to assess the burden imposed to municipalities by their administrative costs. They found that municipalities which spend more funds to sustain their bureaucracy status are less efficient.

\subsection{Geographical or natural determinants}

This group of environmental variables is related to geographical, spatial or natural characteristics. It is explained by four indicators: distance from centre, area, type of municipality and others. 
- Distance from centre and localization effects (11 papers)

This variable measures the geographical distance of the municipality from the regional or district centre. The main hypothesis is that the smaller the distance between the municipality and the centre, the higher the competition between municipalities. Also the access to local public goods provided by the region gets easier. Hence, municipalities closer to the centre would be more efficient. ${ }^{40}$ However, Štastná and Gregor (2015) found that proximity to the regional centre increases efficiency, while distance to district centre has the opposite sign. Otherwise, there are also studies which found that distance from the centre is not statically significant (Boetti et al., 2012).

Conversely, the study of Sampaio de Sousa et al. (2005) used the variable "capital" as a location aspect, arguing that there is a clear efficiency premium for state capitals since those cities tend to present higher efficiency scores relative to other localities with similar characteristics. Similarly, Andrews and Entwistle (2015) introduced a dichotomous variable for local authorities within London, however they did not find significant results. Moreover, Grossman et al. (1999) introduced the number of cities in city's metropolitan statistical area. They found that a greater number of cities in a central city's metropolitan area increase competition and, as a consequence, more technically efficient is the central city. Finally, the study of Radulovic and Dragutinovic (2015) introduced the variable "distance to Route E75 (Motorway A1)" as a location factor, supporting that municipalities closer to the E75 would be more efficient.

- Area (5 papers)

Some studies included the size of local government area measured in squared kilometres. The main hypothesis is that larger areas would have higher costs of infrastructure services. Moreover, smaller administrative areas also tend to be easily managed than bigger ones. So, it is expected to have a negative correlation with efficiency. ${ }^{41}$ Other studies found that city size is not significant in explaining efficiency (Moore et al., 2005).

- Type of municipality (6 papers)

It comprises natural geographical factors that affect the level of municipal efficiency, such as sea, mountain or municipalities located in islands. The first group relates to coastal or sea variables. Coastal municipalities are better able to achieve higher levels of economic efficiency due to their higher levels of development and their greater ability to increase tax receipts. So, a coastal location would have a positive relation to efficiency (Cordero et al., 2016). However, the sea municipalities can be subject to seasonality, which could have a negative correlation with efficiency (Carosi et al., 2014). In addition, Da Cruz and Marques (2014) included a dummy variable to difference municipalities located in islands as well as municipalities located in the mainland near the coast (littoral area). They argue that municipalities located in islands have higher costs when providing some public services and equipment because of its natural constraint, however they showed a positive correlation with efficiency, explaining that in the Portuguese islands there exists a regional government that substitutes the municipality in some of their responsibilities.

The second group relates to mountain or hill variables. The main hypothesis is that municipalities located in the mountain have higher spending levels than non-mountain municipalities, so it

\footnotetext{
${ }^{40}$ Loikkanen and Susiluoto (2005), Afonso and Fernandes (2008), Loikkanen et al. (2011), Štastná and Gregor (2011), Pacheco et al. (2014).
}

${ }^{41}$ Ibrahim and Karim (2004), Sung (2007), Nakazawa (2013), Da Cruz and Marques (2014). 
is negatively correlated with efficiency (Carosi et al., 2014). Similarly, Boetti et al. (2012) found the same results using a dummy for altitude over $600 \mathrm{~m}$. Otherwise, Da Cruz and Marques (2014) included the variable topography (difference between the maximum and minimum altitude) and Agasisti et al. (2015) used the geographical conformation as the range of altitude mountains, however neither studies found significant results.

- Other determinants related to geographical or natural determinants characteristics

Finally, we include other determinants related to geographical or natural characteristics which are not classified in the previous subcategories. Sampaio de Sousa et al. (2005) introduced spatial correlation effects showing the relevance of the neighbourhood in the spatial distribution of the efficiency scores. They found positive spatial correlation, thus indicating that higher efficiency levels tend to spread out to the surrounding localities. Also, Arcelus et al. (2015) included a dummy for the municipalities located in the north of the territory, however it was not significant. Otherwise, Sampaio de Sousa et al. (2005) also found that municipalities located in drought areas were less efficient than their counterparts in more clement areas since these municipalities have more difficulties to provide the required public services to their population. Agasisti et al. (2015) introduced a dummy variable to measure the seismic risk. They concluded that lower seismic risk reduces the expenditures of the municipalities for taking anti-seismic measures, that is, it positively affects efficiency. Finally, Moore et al. (2005) included variables related to weather such as the average precipitation, average snowfall, average temperature, maximum temperature and minimum temperature. Only average temperature and average snowfall were found significant.

\subsection{Institutional and management determinants}

In this section, we have included a group of environmental variables related to institutional and management characteristics of the local governments. It is explained by five indicators: informatization or level of computer usage, mayor and local government employees characteristics, amalgamation, managerial forms and others.

- Informatization or level of computer usage (4 papers)

The variables in this subgroup measure the level of technology used by local government. Ibrahim and Karim (2004) and Sampaio de Sousa et al. (2005) used the level of computer usage, suggesting that it is a powerful tool for management, thus being indicative of a superior and more effective decision-making process since computer utilization eases administrative tasks. Both studies found a positive relationship between the efficiency scores and level of computer utilization. Moreover, Sung (2007) and Seol et al. (2008) attempted to examine the impact of "informatization technology" on local government efficiency. They constructed an index containing variables such as investments and equipments, share of informatization technology personnel and the application of informatization technology to administrative process, among others. Their results confirm a positive and significant correlation between "informatization technology" and efficiency.

- Mayor and local government employees characteristics (10 papers)

On the one hand, some studies included characteristics related to local government's mayor. Loikkanen et al. (2011) studied whether Finnish city managers' characteristics and work 
environment explain differences in cost efficiency. They included variables such as age, education level, gender and work environment (cooperation, contact intensity, etc.). City manager's education level, attitudes towards the participation of workers, attitude concerning the efficiency advantage of private sector relative to public sector and positive view on cooperation with partners were correlated with higher efficiency. Moreover, Boetti et al. (2012) considered mayor's gender and age, arguing that the presence of older mayors significantly reduces inefficiency, while gender is not statistically significant. Also Agasisti et al. (2015) found mayors' gender not statistically significant. In addition, Ibrahim and Karim (2004) introduced the job vacancies in local government and the education level of the municipal managers. However, they did not find significant results. Finally, Grossman et al. (1999) included a variable representing the number of years for the mayor's term, however it is not significant.

On the other hand, some studies included variables related to council employees. Worthington (2000) included the staff per capita, Revelli (2010) used the percentage of employment in financial and real estate services and Sampaio de Sousa et al. (2005) and Fogarty and Mugera (2013) used the employee expenses per capita. Higher employee expenses or higher level of staff per capita were negatively correlated with the efficiency scores. In addition, Loikkanen and Susiluoto (2005) considered the age of council employees, suggesting that employees aged 35-49 seem to be most beneficial to cost efficiency compared to younger or older groups.

- Amalgamation (5 papers)

Amalgamation measures the process where municipalities of some countries were merged in one municipality. Geys (2006) and Geys and Moesen (2009) assessed the effect of the large-scale municipal amalgamation operation in Belgium in 1976 by incorporating a variable equal to the number of communities that were united in one municipality in that year. Only Geys (2006) found significant results, suggesting that a higher number of merging municipalities in one municipality was negatively correlated with efficiency. They argue that their inhabitants are still identified with their old community and the resulting "intra-municipality" competition reduces overall efficiency.

Moreover, Nakazawa (2013) introduced the number of Japanese municipalities that participated in an amalgamation while Nakazawa (2014) measured municipal amalgamation by absorption and by consolidation. They showed that amalgamation has a negative correlation with efficiency because it causes integration costs (slack) for an administrative organization. Finally, Da Cruz and Marques (2014) and Cordero et al. (2016) included the number of parishes in local governments regarding the administrative reform of civil parishes in Portugal, which aimed to reduce the number of local council representatives. Cordero et al. (2016) suggested that the process of amalgamation enhanced the efficiency of more divided municipalities, that is, those with a higher number of civil parishes.

- Managerial forms (11 papers)

As management factors, different studies have included variables related to municipal association (or cooperation), privatization (or externalization), mixed companies and decentralization (agentification). The first category relates to the associated management between two or more municipalities and it includes variables such as municipal association, participation in municipal consortia, joint provision and inter-municipal cooperation. On the one hand, members of a municipal association pool their resources in order to realize economies of scale without giving up their status as autonomous municipalities. Moreover, while local authorities are only controlled by individual voters, the municipal association is also controlled by the politicians of the member municipalities. 
So, the joint provision of municipal services would have a positive correlation with efficiency (Bischoff et al., 2013; Arcelus et al., 2015). On the contrary, Sampaio de Sousa et al. (2005) found that participation in inter-municipal consortia has a negative correlation with efficiency, arguing that only the municipalities that operate on a scale below the optimum have an incentive to join those consortia in an attempt to reduce average costs. Similarly, Loikkanen and Susiluoto (2005) concluded that a big share of services produced by joint municipal organizations also affects efficiency negatively, and Pérez-López et al. (2015) found that inter-municipal cooperation tends to reduce efficiency. Other studies did not find statistically significant results (Bönisch et al., 2011).

The second category is related to the privatization management process and it includes variables such as purchases from private producers, private management or externalization. In this context, some studies found that a big share of privately produced services enhances efficiency (Loikkanen and Susiluoto, 2005; Andrews and Entwistle, 2015). On the contrary, Cuadrado-Ballesteros et al. (2013) showed that externalization and the adoption of contracting-out are harmful to efficiency. Finally, some studies did not find significant differences in efficiency according to the way of management used by the local government (Benito et al., 2010).

The third category is related to mixed management which is measured as mixed companies/firms, or joint service delivery. The adoption of mixed firms, featuring collaboration between the public sector and the private sector, contributes to higher levels of efficiency (Cuadrado-Ballesteros et al., 2013; Pérez-López et al., 2015). Cuadrado-Ballesteros et al. (2013) also included the variable "total decentralization" (measured as the number of functional decentralized agencies created in each municipality such as companies, autonomous organizations, public business entities and foundations), while Pérez-López et al. (2015) measured the agentification level. Both studies showed a negative correlation with efficiency.

Additionally, Boetti et al. (2012) and Agasisti et al. (2015) studied the effects of different managerial forms of waste collection. Boetti et al. (2012) indicated a positive significant correlation only for the cooperative organization among municipalities, suggesting that cost savings result from the advantage of sharing large fixed costs combined with the benefit of increasing expenditure control, while Agasisti et al. (2015) showed that only external service company is associated with efficiency, which is negatively correlated.

- Other determinants related to institutional or managerial characteristics

Finally, we include other determinants related to institutional or managerial characteristics which are not classified in the previous subcategories. Sampaio de Sousa et al. (2005) studied the decision power of municipal councils. They found that the more power yielded to municipal councils, the better the resource utilization since those councils tend to increase the transparency of the budgeting process, which contributes to more effective control over corruption and over the misuse of local funds. Moreover, Hayes and Chang (1990) included the fire rating arguing that local government has the authority to hire and fire other city officials outside the merit system, however they do not find significant results. Andrews and Entwistle (2015) measured the managerial capacity as the expenditure on central administration per resident. Sampaio de Sousa et al. (2005) also included the degree to which the real estate register is up-to-date, which was found to have a negative correlation with efficiency. Moreover, Arcelus et al. (2015) took into consideration the existence of a public comptroller in the municipality. The hypothesis is that higher degree of local supervision should lead to better management practices and more efficiency in the provision of local services.

(C) 2017 The Authors. International Transactions in Operational Research (C) 2017 International Federation of Operational Research Societies 
Finally, Lampe et al. (2015) analyzed the effect of new accounting and budgeting regimes. They found that due to the accrual accounting adoption, municipalities' cost inefficiency decreases.

\section{Conclusions}

In this paper, we have presented a systematic review of the existing literature on local government efficiency along with its determinants. We identified 63 empirical studies on the subject, being the most complete source of references on determinants of local government efficiency analysis up to now. We summarized the environmental variables used in previous literature, as well as the methodologies applied. As the efficiency results depend heavily on the variable selection and methods used, this paper provides a good basis for researchers in the field of local governments' efficiency.

The literature review leads us to four considerations and ways for further research. First, it is necessary to consider the influence of environmental variables on efficiency. If local governments are affected by factors beyond their control, performance analysis should control for this heterogeneity. Therefore, efficiency estimations which do not account for the operational environment have only a limited value.

Second, there is a wide variety of determinants of local government efficiency. Unfortunately, the literature lacks a clear and standard classification for the inclusion of environmental variables in empirical efficiency analyzes. In addition, we note that many determinants present ambiguous effects over efficiency, that is, results from different studies are mixed. This mixed evidence can be explained by the low external validity of the results due to, for example, the different micro- and macro-economic structure, geographical conditions, political and social institutions of countries. In this context, the conclusions and potential policy implications are not necessarily applicable to other jurisdictions, since they are country specific. Our classification of determinants as well as the summary on their impact over efficiency might help to structure future studies on these matters.

Third, past studies interpret their results in a causal way, neglecting the endogeneity issues in the data. The issue of endogenous data in local government efficiency literature has received little attention. The large majority of studies tended to omit variables due to the infeasibility to include a large amount of variables in the analysis (arising from methodological and computational issues) as well as data unavailability. Also, there is a lack of studies that used municipal or individual fixed effects or considered the reversed causality problem. In general, more research on the issue of causality and on how endogeneity biases the efficiency results is needed.

Finally, the most popular methods to include environmental variables with non-parametric methods are based on the two-stage analysis, mainly using Tobit or OLS. In general, it is necessary to apply more advance techniques to incorporate environmental variables, which avoids the problems related to the separability condition from two-stage analysis.

\section{Acknowledgement}

Isabel Narbón-Perpiñá has received funding from Universitat Jaume I (PREDOC/2013/35 and E-2016-04). 


\section{References}

Afonso, A., Fernandes, S., 2008. Assessing and explaining the relative efficiency of local government. The Journal of Socio-Economics 37, 5, 1946-1979.

Afonso, A., Schuknecht, L., Tanzi, V., 2010. Public sector efficiency: evidence for new EU member states and emerging markets. Applied Economics 42, 17, 2147-2164.

Agasisti, T., Dal Bianco, A., Griffini, M., 2015. The public sector fiscal efficiency in Italy: the case of Lombardy municipalities in the provision of the essential public services. Technical Report No. 691, Società Italiana di Economia Pubblica, Università di Pavia, Italy.

Aigner, D., Lovell, C.K., Schmidt, P., 1977. Formulation and estimation of stochastic frontier production function models. Journal of Econometrics 6, 1, 21-37.

Andrews, R., Entwistle, T., 2015. Public-private partnerships, management capacity and public service efficiency. Policy \& Politics 43, 2, 273-290.

Arcelus, F.J., Arocena, P., Cabasés, F., Pascual, P., 2015. On the cost-efficiency of service delivery in small municipalities. Regional Studies 49, 9, 1469-1480.

Asatryan, Z., De Witte, K., 2015. Direct democracy and local government efficiency. European Journal of Political Economy 39, 58-66.

Ashworth, J., Geys, B., Heyndels, B., Wille, F., 2014. Competition in the political arena and local government performance. Applied Economics 46, 19, 2264-2276.

Athanassopoulos, A.D., Triantis, K.P., 1998. Assessing aggregate cost efficiency and the related policy implications for Greek local municipalities. Information Systems and Operational Research 36, 3, 66-83.

Balaguer-Coll, M.T., Prior, D., 2009. Short- and long-term evaluation of efficiency and quality. An application to Spanish municipalities. Applied Economics 41, 23, 2991-3002.

Balaguer-Coll, M.T., Prior, D., Tortosa-Ausina, E., 2007. On the determinants of local government performance: a two-stage nonparametric approach. European Economic Review 51, 2, 425-451.

Balaguer-Coll, M.T., Prior, D., Tortosa-Ausina, E., 2013. Output complexity, environmental conditions, and the efficiency of municipalities. Journal of Productivity Analysis 39, 3, 303-324.

Benito, B., Bastida, F., García, J.A., 2010. Explaining differences in efficiency: an application to Spanish municipalities. Applied Economics 42, 4, 515-528.

Benito, B., Solana, J., Moreno, M.-R., 2015. Explaining efficiency in municipal services providers. Journal of Productivity Analysis 42, 3, 225-239.

Benito-López, B., Moreno-Enguix, M.D.R., Solana-Ibánez, J., 2011. Determinants of efficiency in the provision of municipal street-cleaning and refuse collection services. Waste Management 31, 6, 1099-1108.

Bischoff, I., Bönisch, P., Haug, P., Illy, A., 2013. Vertical grants and local public efficiency. Technical Report No. 1/2013, Halle Institute for Economic Research (IWH), Germany.

Boetti, L., Piacenza, M., Turati, G., 2012. Decentralization and local governments' performance: how does fiscal autonomy affect spending efficiency? FinanzArchiv: Public Finance Analysis 68, 3, 269-302.

Bönisch, P., Haug, P., Illy, A., Schreier, L., 2011. Municipality size and efficiency of local public services: does size matter? Technical Report No. 18/2011, Halle Institute for Economic Research (IWH), Germany.

Borge, L.-E., Falch, T., Tovmo, P., 2008. Public sector efficiency: the roles of political and budgetary institutions, fiscal capacity, and democratic participation. Public Choice 136, 3, 475-495.

Bosch, N., Pedraja, F., Suárez-Pandiello, J., 2000. Measuring the efficiency of Spanish municipal refuse collection services. Local Government Studies 26, 3, 71-90.

Bosch-Roca, N., Mora-Corral, A.J., Espasa-Queralt, M., 2012. Citizen control and the efficiency of local public services. Environment and Planning C: Government and Policy 30, 2, 248.

Bruns, C., Himmler, O., 2011. Newspaper circulation and local government efficiency. The Scandinavian Journal of Economics 113, 2, 470-492.

Carosi, L., D’Inverno, G., Ravagli, L., 2014. Global public spending efficiency in Tuscan municipalities. Technical Report No. 175, Dipartimento di Economia e Management (DEM), University of Pisa, Italy.

Cazals, C., Florens, J.-P., Simar, L., 2002. Nonparametric frontier estimation: a robust approach. Journal of Econometrics $106,1,1-25$.

(C) 2017 The Authors International Transactions in Operational Research (C) 2017 International Federation of Operational Research Societies 
Cordero, J.M., Pedraja-Chaparro, F., Pisaflores, E.C., Polo, C., 2016. Efficiency assessment of Portuguese municipalities using a conditional nonparametric approach. Technical Report No. 70674, Munich University Library, Germany.

Cuadrado-Ballesteros, B., García-Sánchez, I.M., Prado-Lorenzo, J.M., 2013. Effect of modes of public services delivery on the efficiency of local governments: a two-stage approach. Utilities Policy 26, 2, 23-35.

Da Cruz, N.F., Marques, R.C., 2014. Revisiting the determinants of local government performance. Omega 44, 91-103.

Daraio, C., Simar, L., 2005. Introducing environmental variables in nonparametric frontier models: a probabilistic approach. Journal of Productivity Analysis 24, 1, 93-121.

Daraio, C., Simar, L., 2007. Conditional nonparametric frontier models for convex and nonconvex technologies: a unifying approach. Journal of Productivity Analysis 28, 1-2, 13-32.

De Borger, B., Kerstens, K., 1996a. Cost efficiency of Belgian local governments: a comparative analysis of FDH, DEA, and econometric approaches. Regional Science and Urban Economics 26, 2, 145-170.

De Borger, B., Kerstens, K., 1996b. Radial and nonradial measures of technical efficiency: an empirical illustration for Belgian local governments using an FDH reference technology. Journal of Productivity Analysis 7, 1, 41-62.

De Borger, B., Kerstens, K., Moesen, W., Vanneste, J., 1994. Explaining differences in productive efficiency: an application to Belgian municipalities. Public Choice 80, 3, 339-358.

De Witte, K., Kortelainen, M., 2013. What explains the performance of students in a heterogeneous environment? Conditional efficiency estimation with continuous and discrete environmental variables. Applied Economics 45, 17, 2401-2412.

De Witte, K., Marques, R.C., 2009. Capturing the environment, a metafrontier approach to the drinking water sector. International Transactions in Operational Research 16, 2, 257-271.

Doumpos, M., Cohen, S., 2014. Applying Data Envelopment Analysis on accounting data to assess and optimize the efficiency of Greek local governments. Omega 46, 74-85.

Eeckaut, P., Tulkens, H., Jamar, M.-A., 1993. Cost efficiency in Belgian municipalities. In Fried, H.O., Lovell, C.K., Schmidt, S.S. (eds) The Measurement of Productive Efficiency-Techniques and Applications. Oxford University Press, New York, pp. 300-334.

Fogarty, J., Mugera, A., 2013. Local government efficiency: evidence from Western Australia. Australian Economic Review $46,3,300-311$.

Fried, H.O., Lovell, C.K., Schmidt, S.S., 2008. The Measurement of Productive Efficiency and Productivity Growth. Oxford University Press, New York.

García-Sánchez, I.M., 2006a. Efficiency measurement in Spanish local government: the case of municipal water services. Review of Policy Research 23, 2, 355-372.

García-Sánchez, I.M., 2006b. Estimation of the effect of environmental conditions on technical efficiency: the case of fire services. Revue d'Économie Régionale \& Urbaine 4, 597-614.

Geys, B., 2006. Looking across borders: a test of spatial policy interdependence using local government efficiency ratings. Journal of Urban Economics 60, 3, 443-462.

Geys, B., Heinemann, F., Kalb, A., 2010. Voter involvement, fiscal autonomy and public sector efficiency: evidence from German municipalities. European Journal of Political Economy 26, 2, 265-278.

Geys, B., Heinemann, F., Kalb, A., 2013. Local government efficiency in German municipalities. Raumforschung und Raumordnung 71, 4, 283-293.

Geys, B., Moesen, W., 2009. Exploring sources of local government technical inefficiency: evidence from Flemish municipalities. Public Finance and Management 9, 1, 1-29.

Giménez, V.M. and Prior, D., 2007. Long- and short-term cost efficiency frontier evaluation: evidence from Spanish local governments. Fiscal Studies 28, 1, 121-139.

Grossman, P.J., Mavros, P., Wassmer, R.W., 1999. Public sector technical inefficiency in large US cities. Journal of Urban Economics 46, 2, 278-299.

Hayes, K., Chang, S., 1990. The relative efficiency of city manager and mayor-council forms of government. Southern Economic Journal 57, 1, 167-177.

Helland, L., Sørensen, R.J., 2015. Partisan bias, electoral volatility, and government efficiency. Electoral Studies 39, $117-128$.

Ibrahim, F., Karim, M., 2004. Efficiency of local governments in Malaysia and its correlates. International Journal of Management Studies 11, 1, 57-70.

(c) 2017 The Authors.

International Transactions in Operational Research @ 2017 International Federation of Operational Research Societies 
Kalb, A., 2010. The impact of intergovernmental grants on cost efficiency: theory and evidence from German municipalities. Economic Analysis and Policy 40, 1, 23-48.

Kalb, A., 2012. What determines local governments' cost-efficiency? The case of road maintenance. Regional Studies 48, 9, 1483-1498.

Kalb, A., Geys, B., Heinemann, F., 2012. Value for money? German local government efficiency in a comparative perspective. Applied Economics 44, 2, 201-218.

Kalseth, J., Rattsø, J., 1995. Spending and overspending in local government administration: a minimum requirement approach applied to Norway. European Journal of Political Economy 11, 2, 239-251.

Lampe, H., Hilgers, D., Ihl, C., 2015. Does accrual accounting improve municipalities' efficiency? Evidence from Germany. Applied Economics 47, 41, 4349-4363.

Lo Storto, C., 2016. The trade-off between cost efficiency and public service quality: a non-parametric frontier analysis of Italian major municipalities. Cities 51, 52-63.

Loikkanen, H.A., Susiluoto, I., 2005. Cost efficiency of Finnish municipalities in basic service provision 1994-2002. Urban Public Economics Review 4, 39-64.

Loikkanen, H.A., Susiluoto, I., Funk, M., 2011. The role of city managers and external variables in explaining efficiency differences of Finnish municipalities. Technical Report No. 312, Helsinki Centre for Economic Research (HECER), University of Helsinki, Finland.

Lorenzo, J.M.P., Sánchez, I.M.G., 2007. Efficiency evaluation in municipal services: an application to the street lighting service in Spain. Journal of Productivity Analysis 27, 3, 149-162.

Mastromarco, C., Simar, L., 2015. Effect of FDI and time on catching up: new insights from a conditional nonparametric frontier analysis. Journal of Applied Econometrics 30, 5, 826-847.

Meeusen, W., Van den Broeck, J., 1977. Efficiency estimation from Cobb-Douglas production functions with composed error. International Economic Review 18, 2, 435-444.

Monkam, N.F., 2014. Local municipality productive efficiency and its determinants in South Africa. Development Southern Africa 31, 2, 275-298.

Moore, A., Nolan, J., Segal, G.F., 2005. Putting out the trash: measuring municipal service efficiency in US cities. Urban Affairs Review 41, 2, 237-259.

Nakazawa, K., 2013. Cost inefficiency of municipalities after amalgamation. Procedia Economics and Finance 5, 581-588.

Nakazawa, K., 2014. Does the method of amalgamation affect cost inefficiency of the new municipalities? Open Journal of Applied Sciences 4, 4, 143-154.

Narbón-Perpiñá, I., De Witte, K., 2017. Local governments' efficiency: a systematic literature review—Part I. International Transactions in Operational Research, doi:10.1111/itor.12364.

Nikolov, M., Hrovatin, N., 2013. Cost efficiency of Macedonian municipalities in service delivery: does ethnic fragmentation matter? Lex Localis 11, 3, 743 .

Pacheco, F., Sanchez, R., Villena, M., 2014. A longitudinal parametric approach to estimate local government efficiency. Technical Report No. 54918, Munich University Library, Germany.

Pérez-López, G., Prior, D., Zafra-Gómez, J.L., 2015. Rethinking New Public Management delivery forms and efficiency: long-term effects in Spanish local government. Journal of Public Administration Research and Theory 25, 4, 11571183.

Pevcin, P., 2014a. Costs and efficiency of municipalities in Slovenia. Lex Localis 12, 3, 417-429.

Pevcin, P., 2014b. Efficiency levels of sub-national governments: a comparison of SFA and DEA estimations. The TQM Journal 26, 3, 275-283.

Radulovic, B., Dragutinović S., 2015. Efficiency of local self-governments in Serbia: an SFA approach. Industrija 43, 3, $123-142$.

Revelli, F., 2010. Spend more, get more? An inquiry into English local government performance. Oxford Economic Papers $62,1,185-207$.

Revelli, F., Tovmo, P., 2007. Revealed yardstick competition: local government efficiency patterns in Norway. Journal of Urban Economics 62, 1, 121-134.

Sampaio de Sousa, M.C., Cribari-Neto, F., Stosic, B.D., 2005. Explaining DEA technical efficiency scores in an outlier corrected environment: the case of public services in Brazilian municipalities. Brazilian Review of Econometrics 25, 2, 287-313.

(c) 2017 The Authors.

International Transactions in Operational Research @ 2017 International Federation of Operational Research Societies 
Seol, H., Lee, H., Kim, S., Park, Y., 2008. The impact of information technology on organizational efficiency in public services: a DEA-based DT approach. Journal of the Operational Research Society 59, 2, 231-238.

Simar, L., Wilson, P.W., 2007. Estimation and inference in two-stage, semi-parametric models of production processes. Journal of Econometrics 136, 1, 31-64.

Sørensen, R.J., 2014. Political competition, party polarization, and government performance. Public Choice 161, 3, $427-450$.

Štastná, L., Gregor, M., 2011. Local government efficiency: evidence from the Czech municipalities. Technical Report No. 14/2011, Institute of Economic Studies, Charles University Prague, Czech Republic.

Štastná, L., Gregor, M., 2015. Public sector efficiency in transition and beyond: evidence from Czech local governments. Applied Economics 47, 7, 680-699.

Stevens, P.A., 2005. Assessing the performance of local government. National Institute Economic Review 193, 1, 90-101.

Sung, N., 2007. Information technology, efficiency and productivity: evidence from Korean local governments. Applied Economics 39, 13, 1691-1703.

Worthington, A.C., 2000. Cost efficiency in Australian local government: a comparative analysis of mathematical programming and econometrical approaches. Financial Accountability \& Management 16, 3, 201-223.

Worthington, A.C., Dollery, B.E., 2000. Measuring efficiency in local governments' planning and regulatory function. Public Productivity \& Management Review 29, 2, 469-485.

Worthington, A.C., Dollery, B.E., 2001. Measuring efficiency in local government: an analysis of New South Wales municipalities' domestic waste management function. Policy Studies Journal 29, 2, 232-249.

Yusfany, A., 2015. The efficiency of local governments and its influence factors. International Journal of Technology Enhancements and Emerging Engineering Research 4, 10, 219-241. 


\section{Appendix}

Table A1

Approaches to incorporate environmental variables in the efficiency estimation

\section{A. Non-parametric approaches}

\section{Two-stage approach}

\subsection{Tobit}

De Borger et al. (1994), De Borger and Kerstens (1996a, 1996b), Worthington (2000), Ibrahim and Karim (2004), Moore et al. (2005), Giménez and Prior (2007), Sung (2007), Afonso and Fernandes (2008), Seol et al. (2008), Balaguer-Coll and Prior (2009), Boetti et al. (2012), Bosch-Roca et al. (2012), Carosi et al. (2014), Da Cruz and Marques (2014), Monkam (2014), Yusfany (2015)

\subsection{OLS}

De Borger and Kerstens (1996a), Athanassopoulos and Triantis (1998), Loikkanen and Susiluoto (2005), Revelli and Tovmo (2007), Borge et al. (2008), Bruns and Himmler (2011), Loikkanen et al. (2011), Fogarty and Mugera (2013), Da Cruz and Marques (2014), Sørensen (2014), Andrews and Entwistle (2015)

\subsection{Single and double bootstrap methods (Simar and Wilson, 2007)}

Bönisch et al. (2011), Bosch-Roca et al. (2012), Bischoff et al. (2013), Cuadrado-Ballesteros et al. (2013), Fogarty and Mugera (2013), Ashworth et al. (2014), Da Cruz and Marques (2014), Doumpos and Cohen (2014), Agasisti et al. (2015), Pérez-López et al. (2015), Lo Storto (2016)

1.4. Other approaches: non-parametric Kernel regression (Nadaraya-Watson), bivariate density functions, generalized least squares, Kendall $\tau$ test, linear regression model, quantile regression

Sampaio de Sousa et al. (2005), Balaguer-Coll et al. (2007), Benito et al. (2010), Nikolov and Hrovatin (2013), Helland and Sørensen (2015)

\section{Metafrontier}

Balaguer-Coll et al. (2013)

3. Conditional efficiency (Cazals et al., 2002; Daraio and Simar, 2005, 2007; Mastromarco and Simar, 2015)

Asatryan and De Witte (2015), Cordero et al. (2016)

B. Parametric approaches

1. Single-stage approach

Arcelus et al. (2015), Boetti et al. (2012), Geys and Moesen (2009), Geys et al. (2010), Geys et al. (2013), Grossman et al. (1999), Hayes and Chang (1990), Kalb (2010), Kalb et al. (2012), Lampe et al. (2015), Nakazawa (2013, 2014), Nikolov and Hrovatin (2013), Pacheco et al. (2014), Pevcin (2014a, 2014b), Radulovic and Dragutinović (2015), Štastná and Gregor (2011), Štastná and Gregor (2015))

\section{Two-stage approach}

\subsection{Tobit}

De Borger and Kerstens (1996a), Athanassopoulos and Triantis (1998), Worthington (2000)

\subsection{OLS}

De Borger and Kerstens (1996a), Geys (2006) 
Table A2

Classification of non-discretionary variables considered on local governments efficiency

Category Variables

1. Social and demographic determinants

Population density

Population growth

Population size

Age distribution population

(share of young people, share of retired people, aging index)

Education level

Immigration share and ethnic diversity

Share of homeowners

2. Economic determinants

Other related social and demographic characteristics

2. Economic determinants

Unemployment

Citizen's income or purchasing power

Economic status

Tourism

Commercial activity

Industrial activity

Other related economic characteristics

3. Political determinants

Ideological position

Political concentration/fragmentation and strength

(Herfindahl index, coalition parties, majority, strength)

Voter turnout and potential electors

Re-election and number of years for elections

Other related politic characteristics

4. Financial determinants

Self-generated revenues

Transfers or grants

Debt or financial liabilities

Fiscal surplus

Infrastructure investments

Other related financial characteristics

5. Geographical and natural determinants

Distance from the centre and localization effects

Area

Type of municipalities

(sea, mountain)

Other related to geographical or natural characteristics

6. Institutional and management determinants Informatization or level of computer usage

Mayor and local government employees characteristics

Amalgamation

Managerial forms

(municipal cooperation, externalization, mixed firms, agentification)

Other related to institutional or management characteristics

(C) 2017 The Authors.

International Transactions in Operational Research (C) 2017 International Federation of Operational Research Societies 
Table A3

Overview of determinants of efficiency in local governments

Variables
1. Social determinants
Population density

Population growth

Population size

Age distribution of the population

Education level

Immigration share and ethnic diversity

Share of homeowners Other related social and demographic characteristics

2. Economic determinants Unemployment
Kalseth and Rattsø (1995), De Borger and Kerstens (1996a), Athanassopoulos and Triantis (1998), Loikkanen and Susiluoto (2005), Sampaio de Sousa et al. (2005), Geys (2006), Giménez and Prior (2007), Revelli and Tovmo (2007), Sung (2007), Afonso and Fernandes (2008), Geys and Moesen (2009), Geys et al. (2010), Kalb (2010), Revelli (2010), Bönisch et al. (2011), Bruns and Himmler (2011), Loikkanen et al. (2011), Boetti et al. (2012), Kalb et al. (2012), Balaguer-Coll et al. (2013), Bischoff et al. (2013), Fogarty and Mugera (2013), Geys et al. (2013), Ashworth et al. (2014), Carosi et al. (2014), Da Cruz and Marques (2014), Doumpos and Cohen (2014), Pevcin (2014a, 2014b), Agasisti et al. (2015), Andrews and Entwistle (2015), Arcelus et al. (2015), Lampe et al. (2015), Radulovic and Dragutinović (2015), Yusfany (2015), Cordero et al. (2016) Lo Storto (2016)

Kalseth and Rattsø (1995), Afonso and Fernandes (2008), Bönisch et al. (2011), Balaguer-Coll et al. (2013), Bischoff et al. (2013), Monkam (2014)

De Borger et al. (1994), Kalseth and Rattsø (1995), Grossman et al. (1999), Loikkanen and Susiluoto (2005), Balaguer-Coll et al. (2007), Giménez and Prior (2007), Sung (2007), Geys and Moesen (2009), Benito et al. (2010), Revelli (2010), Bruns and Himmler (2011), Loikkanen et al. (2011), Štastná and Gregor (2011), Boetti et al. (2012), Nakazawa (2013, 2014), Ashworth et al. (2014), Carosi et al. (2014), Doumpos and Cohen (2014), Sørensen (2014), Andrews and Entwistle (2015), Asatryan and De Witte (2015) Pérez-López et al. (2015), Štastná and Gregor (2015)

Bönisch et al. (2011), Bruns and Himmler (2011), Bosch-Roca et al. (2012), Bischoff et al. (2013), Nakazawa (2013), Da Cruz and Marques (2014), Nakazawa (2014), Agasisti et al. (2015), Andrews and Entwistle (2015), Radulovic and Dragutinović (2015)

De Borger et al. (1994), De Borger and Kerstens (1996a, 1996b), Ibrahim and Karim (2004), Loikkanen and Susiluoto (2005), Afonso and Fernandes (2008), Geys and Moesen (2009), Kalb (2010), Revelli (2010), Bruns and Himmler (2011), Loikkanen et al. (2011), Štastná and Gregor (2011), Bosch-Roca et al. (2012), Da Cruz and Marques (2014), Monkam (2014), Radulovic and Dragutinović (2015), Štastná and Gregor (2015)

Hayes and Chang (1990), Revelli (2010), Bruns and Himmler (2011), Bosch-Roca et al. (2012), Nikolov and Hrovatin (2013), Andrews and Entwistle (2015), Lampe et al. (2015)

Hayes and Chang (1990), Geys (2006), Geys and Moesen (2009)

Revelli (2010), Bruns and Himmler (2011), Nakazawa (2013), Da Cruz and Marques (2014), Agasisti et al. (2015), Andrews and Entwistle (2015); Lo Storto (2016)

Loikkanen and Susiluoto (2005), Balaguer-Coll and Prior (2009), Geys and Moesen (2009), Kalb (2010), Revelli (2010), Bönisch et al. (2011), Loikkanen et al. (2011), Kalb et al. (2012), Geys et al. (2013), Pevcin (2014a, 2014b), Lampe et al. (2015), Pérez-López et al. (2015), Radulovic and Dragutinović (2015), Cordero et al. (2016)

Continued 
Table A3

Continued

\begin{tabular}{l} 
Variables \\
\hline $\begin{array}{l}\text { Citizen's income or } \\
\text { purchasing power }\end{array}$ \\
Municipal economic \\
situation \\
Tourism
\end{tabular}

Tourism

Commercial activity

Industrial activity

Other related economic characteristics

\section{Political determinants}

Ideological position

Political concentration/fragmentation and strength

Voter turnout and democratic participation

Re-election and number of years for elections

Other related political characteristics

\section{Studies}

De Borger et al. (1994), De Borger and Kerstens (1996a, 1996b), Ibrahim and Karim (2004), Loikkanen and Susiluoto (2005), Sampaio de Sousa et al. (2005), Geys (2006), Giménez and Prior (2007), Afonso and Fernandes (2008), Balaguer-Coll and Prior (2009), Geys and Moesen (2009), Benito et al. (2010), Afonso et al. (2010), Bruns and Himmler (2011), Boetti et al. (2012), Bosch-Roca et al. (2012), Balaguer-Coll et al. (2013), Cuadrado-Ballesteros et al. (2013), Nikolov and Hrovatin (2013), Ashworth et al. (2014), Da Cruz and Marques (2014), Monkam (2014), Agasisti et al. (2015), Asatryan and De Witte (2015), Yusfany (2015), Cordero et al. (2016)

Sampaio de Sousa et al. (2005), Revelli (2010), Balaguer-Coll et al. (2013), Fogarty and Mugera (2013), Andrews and Entwistle (2015), Lo Storto (2016)

Sampaio de Sousa et al. (2005), Giménez and Prior (2007), Balaguer-Coll and Prior (2009), Geys and Moesen (2009), Kalb (2010), Benito et al. (2010), Bosch-Roca et al. (2012), Kalb et al. (2012), Cuadrado-Ballesteros et al. (2013), Carosi et al. (2014), Da Cruz and Marques (2014), Lampe et al. (2015), Pérez-López et al. (2015)

Giménez and Prior (2007), Sung (2007), Balaguer-Coll and Prior (2009), Bosch-Roca et al. (2012)

Giménez and Prior (2007), Geys and Moesen (2009)

Sampaio de Sousa et al. (2005), Geys and Moesen (2009), Revelli (2010), Balaguer-Coll et al. (2013), Da Cruz and Marques (2014)

De Borger et al. (1994), De Borger and Kerstens (1996a, 1996b), Geys (2006), Borge et al. (2008), Geys and Moesen (2009), Geys et al. (2010), Kalb (2010), Revelli (2010), Benito et al. (2010), Bruns and Himmler (2011), Loikkanen et al. (2011), Štastná and Gregor (2011), Boetti et al. (2012), Kalb et al. (2012), Ashworth et al. (2014), Da Cruz and Marques (2014), Doumpos and Cohen (2014), Sørensen (2014), Agasisti et al. (2015), Asatryan and De Witte (2015), Andrews and Entwistle (2015), Helland and Sørensen (2015), Pérez-López et al. (2015), Štastná and Gregor (2015), Cordero et al. (2016)

Eeckaut et al. (1993), De Borger et al. (1994), Athanassopoulos and Triantis (1998), Geys (2006), Balaguer-Coll et al. (2007), Revelli and Tovmo (2007), Borge et al. (2008), Geys et al. (2010), Kalb (2010), Revelli (2010), Bruns and Himmler (2011), Loikkanen et al. (2011), Štastná and Gregor (2011), Kalb et al. (2012), Cuadrado-Ballesteros et al. (2013), Geys et al. (2013), Nikolov and Hrovatin (2013), Ashworth et al. (2014), Doumpos and Cohen (2014), Monkam (2014), Pacheco et al. (2014), Sørensen (2014), Helland and Sørensen (2015), Pérez-López et al. (2015), Yusfany (2015)

Revelli and Tovmo (2007), Borge et al. (2008), Geys et al. (2010), Loikkanen et al. (2011), Štastná and Gregor (2011), Bosch-Roca et al. (2012), Da Cruz and Marques (2014), Asatryan and De Witte (2015), Štastná and Gregor (2015)

Boetti et al. (2012), Carosi et al. (2014), Da Cruz and Marques (2014), Doumpos and Cohen (2014), Agasisti et al. (2015)

Grossman et al. (1999), Bruns and Himmler (2011) 
Table A3

Continued

Variables Studies

4. Financial determinants

Self-generated revenues

Transfers or grants

Debt or financial liabilities

Fiscal surplus

Infrastructure investments

Other related financial characteristics
De Borger and Kerstens (1996a, 1996b), Athanassopoulos and Triantis (1998), Moore et al. (2005), Balaguer-Coll et al. (2007), Revelli and Tovmo (2007), Sung (2007), Borge et al. (2008), Balaguer-Coll and Prior (2009), Benito et al. (2010), Štastná and Gregor (2011), Boetti et al. (2012), Bosch-Roca et al. (2012), Fogarty and Mugera (2013), Nikolov and Hrovatin (2013), Ashworth et al. (2014), Carosi et al. (2014), Da Cruz and Marques (2014), Doumpos and Cohen (2014), Monkam (2014), Agasisti et al. (2015), Arcelus et al. (2015), Pérez-López et al. (2015), Štastná and Gregor (2015), Yusfany (2015)

De Borger and Kerstens (1996a, 1996b), Athanassopoulos and Triantis (1998), Grossman et al. (1999), Worthington (2000), Loikkanen and Susiluoto (2005), Geys (2006), Balaguer-Coll et al. (2007), Borge et al. (2008), Balaguer-Coll and Prior (2009), Geys and Moesen (2009), Geys et al. (2010), Kalb (2010), Bönisch et al. (2011), Štastná and Gregor (2011), Boetti et al. (2012), Bosch-Roca et al. (2012), Bischoff et al. (2013), Ashworth et al. (2014), Da Cruz and Marques (2014), Doumpos and Cohen (2014), Pacheco et al. (2014), Agasisti et al. (2015),

Pérez-López et al. (2015), Štastná and Gregor (2015), Yusfany (2015)

Worthington (2000), Geys (2006), Balaguer-Coll et al. (2007), Revelli and Tovmo (2007), Balaguer-Coll and Prior (2009), Geys and Moesen (2009), Benito et al. (2010), Bönisch et al. (2011), Štastná and Gregor (2011), Bischoff et al. (2013), Ashworth et al. (2014), Da Cruz and Marques (2014), Pérez-López et al. (2015), Cordero et al. (2016)

Geys (2006), Geys and Moesen (2009), Ashworth et al. (2014), Agasisti et al. (2015), Pérez-López et al. (2015), Yusfany (2015)

Athanassopoulos and Triantis (1998), Štastná and Gregor (2011), Doumpos and Cohen (2014), Pacheco et al. (2014), Agasisti et al. (2015), Arcelus et al. (2015), Stastná and Gregor (2015)

Worthington (2000), Borge et al. (2008), Benito et al. (2010), Kalb (2010), Revelli (2010), Boetti et al. (2012), Da Cruz and Marques (2014), Doumpos and Cohen (2014), Agasisti et al. (2015), Andrews and Entwistle (2015), Pérez-López et al. (2015)

\section{Geographical or natural determinants}

Distance from centre and Grossman et al. (1999), Loikkanen and Susiluoto (2005), Sampaio de Sousa et al. localisation effects (2005), Afonso and Fernandes (2008), Loikkanen et al. (2011), Štastná and Gregor (2011), Boetti et al. (2012), Pacheco et al. (2014), Andrews and Entwistle (2015), Radulovic and Dragutinović (2015), Štastná and Gregor (2015)

Area Ibrahim and Karim (2004), Moore et al. (2005), Sung (2007), Nakazawa (2013), Da Cruz and Marques (2014)

Type of municipality

(Sea, Mountain)

Other related to geographical or natural characteristics

\section{Institutional and management determinants}

Informatisation or level of Ibrahim and Karim (2004), Sampaio de Sousa et al. (2005), Sung (2007), Seol et al. computer usage
Boetti et al. (2012), Carosi et al. (2014), Da Cruz and Marques (2014), Agasisti et al. (2015), Cordero et al. (2016)

Moore et al. (2005), Sampaio de Sousa et al. (2005), Agasisti et al. (2015), Arcelus et al. (2015) (2008) 
Table A3

Continued

\begin{tabular}{ll}
\hline Variables & Studies \\
\hline $\begin{array}{l}\text { Mayor and local } \\
\text { government employees }\end{array}$ & $\begin{array}{c}\text { Grossman et al. (1999), Worthington (2000), Ibrahim and Karim (2004), Loikkanen } \\
\text { and Susiluoto (2005), Sampaio de Sousa et al. (2005), Revelli (2010), Loikkanen }\end{array}$ \\
Amalgamation & et al. (2011), Boetti et al. (2012), Fogarty and Mugera (2013), Agasisti et al. (2015) \\
& Geys (2006), Geys and Moesen (2009), Nakazawa (2013), Da Cruz and Marques \\
(2014), Nakazawa (2014) & \\
Loikkanen and Susiluoto (2005), Sampaio de Sousa et al. (2005), Benito et al. (2010), & Bönisch et al. (2011), Boetti et al. (2012), Bischoff et al. (2013), \\
& Cuadrado-Ballesteros et al. (2013), Agasisti et al. (2015), Andrews and Entwistle \\
(2015), Arcelus et al. (2015), Pérez-López et al. (2015) & Hayes and Chang (1990), Moore et al. (2005), Sampaio de Sousa et al. (2005), \\
$\begin{array}{l}\text { Other related to } \\
\text { institutional and } \\
\text { characteristics }\end{array}$ & Agasisti et al. (2015), Andrews and Entwistle (2015), Arcelus et al. (2015), \\
\hline
\end{tabular}

